\title{
SENSITIVITAS KAKI PASIEN DIABETES MELITUS TIPE II DI RUMAH SAKIT MUHAMMADIYAH PALEMBANG
}

\author{
Sukron \\ Program Studi IImu Keperawatan STIKes Muhammadiyah Palembang \\ Sukronmns@gmail.com
}

\begin{abstract}
ABSTRAK
Latar Belakang : Meningkatnya angka penyakit diabetes melitus tipe 2 khususnya di Indonesia bersamaan dengan meningkatnya komplikasi salah satunya diabetic foot ulcer yang juga merupakan faktor terjadinya gangguan sensitivitas pada kaki. Pencegahan dapat dilakukan dengan mengukur sensitivitas kaki dengan menggunkan monofilmen test. Tujuan Penelitian : Untuk mengetahui gambaran tingkat sensitivitas kaki pada penderita diabetes melitus tipe 2 di Rumah Sakit Muhammadiyah Palembang. Metode Penelitian : Penelitian ini merupakan penelitian dengan metode Deskripti Analitikdengan pendekatan kuantitatif. Teknik sampling menggunakan convenience sampling pada pasien diabetes melitus tipe 2 di Rumah Sakit Muhammadiyah Palembang yang berjumlah 60 responden. Hasil : Hasil penelitian menunjukkan bahwa rata-rata pasien diabetes melitus tipe 2 berusia 59,45 tahun dan sebagaian besar berjenis kelamin laki-laki dengan tingkat pendidikan sebesar $33,3 \%$ SD dan 33,3\% SMA. Rerata responden juga menderita diabetes melitus tipe 2 selama 3,58 tahun dengan sebagian besar responden tidak berkerja dan tidak berolahraga. Serta tingkat sensitivitas kaki pada pasien diabetes melitus tipe 2yang tidak ada rasa dengan frekuensi tertinggi yaitu pada dorsal kaki sebanyak 25 orang $(41,67 \%)$, metatarsal head ke-1 sebanyak 23 orang $(38,33 \%)$, Midfoot bagian Medial sebanyak 22 orang $(36,67)$, jari tengah sebnayk 21 orang (35\%), metatarsal head ke-3 sebanyak 20 orang (33,33\%), Midfoot bagian lateral sebanyak 20 orang $(33,33 \%)$, Tumit sebanyak 18 orang $(30 \%)$, jari kelingking sebanyak 18 orang $(30 \%)$, metatarsal haed ke-2 sebanyak 17 orang $(28,33 \%)$, dan terendah yaitu pada jempol kaki dengan frekuensi 12 responden (20\%). Kesimpulan : sensitivitas kaki pada pasien diabetes melitus tipe II yaitu terendah pada dorsal kaki.
\end{abstract}

Kata kunci : Gambaran, Sensitivitas Kaki, Pada Pasien Diabetes Melitus Tipe II.

\section{ABSTRACT}

Background: The increasing number of type I/ diabetes mellitus, especially in Indonesia together with the increase in complications, one of which is diabetic foot ulcer, which is also a factor in sensitivity to the feet. Prevention can be done by measuring foot sensitivity by using a monofilment test. Objective: To find out the description of the level of sensitivity of the foot in patients with type II diabetes mellitus patients in Muhammadiyah Hospital Palembang. Method of Researvh: This research is a research with Analytic Descriptive method with quantitative approach. The sampling technique uses convenience sampling in patients with type II diabetes mellitus at Muhammadiyah Hospital Palembang, amounting to 60 respondents. Result of Research: The results showed that the average type II diabetes mellitus patients were 59.45 years old and most were male with education level of 33.3\% elementary school and 33.3\% high school. The average respondent also suffered from type II diabetes mellitus for 3.58 years with most respondents not working and not exercising. And the level of sensitivity of the foot in 
patients with type II diabetes mellitus that does not have the highest frequency is the dorsal foot of 25 people (41.67\%), the first metatarsal head of 23 people (38.33\%), Midfoot of the Medial section of 22 people (36.67), middle fingers 21 people (35\%), 3rd metatarsal head as many as 20 people (33.33\%), lateral midfoot as many as 20 people (33.33\%), Heel as many as 18 people (30\%), the pinky finger was 18 people (30\%), the second metatarsal haed were 17 people (28.33\%), and the lowest was the big toe with a frequency of 12 respondents (20\%). Conclusion: Foot sensitivity in type II diabetes mellitus patients is lowest in the dorsal foot.

Keyword: Dercription, Foot Sencitivity, Type II Diabetes Mellitus Patients

\section{PENDAHULUAN}

Kesehatan adalah kondisi dimana keadaan dan kesejahteraan yang meliputi kondisi fisik, mental maupun social (WHO, 2014).Masalah utama kesehatan yang sering dijumpai pada orang dewasa adalah penyakit yang tidak menular (non communicable) salah satunya adalah Diabetes Melitus.Diabetes Melitus (DM) merupakan suatu penyakit tidak menular yang meningkat jumlahnya dimasa yang datang karena perubahan gaya hidup.Penyakit tidak menular tersebut merupakan pembunuh utama di Indonesia di bandingkan dengan penyakit menular. Oleh sebab itu pemerintah mengeluarkan program kesehatan yaitu (Germas) gerakan masyarakat sehat untuk mengatasi masalah Diabetes Melitus.

Berdasarkan data dari WHO yang diperbarui Juli 2016, jumlah dibetes adalah sebanyak 422 juta orang atau. WHO juga mengestimasikan bahwa kasus kematian yang di akibatkan diabetes pada tahun 2015 adalah sebesar 1,6 juta, sementara 2,2 juta kasus kematian pada tahun 2012 berkaitan dengan tingginya sensitivitas kaki. Berdasarkan data International Diabetes Federation (IDF) tahun 2017 melaporkan Diabetes di Indonesia masih menunjukkan kecenderungan meningkat. Indonesia adalah negara peringkat keenam di dunia setelah Tiongkok, India, Amerika Serikat, Brazil dan Meksiko dengan jumlah penyandang Diabetes pada penduduk dewasa sebanyak 10 juta dengan jumlah populasi dewasa sekitar 161.5 juta.

Riset Kesehatan Dasar (Riskesdas, 2018) memperlihatkan peningkatan angka prevalensi Diabetes yang cukup signifikan, yaitu dari $6,9 \%$ di tahun 2013 menjadi 8,5\% di tahun 2018; sehingga estimasi jumlah penderita di Indonesia mencapai lebih dari 16 juta orang yang kemudian berisiko terkena penyakit lain, seperti: serangan jantung, stroke, kebutaan dan gagal ginjal bahkan dapat menyebabkan kelumpuhan dan kematian.Data Jaminan Kesehatan Nasional (JKN) juga menunjukkan peningkatan jumlah kasus dan pembiayaan pelayanan Diabetes di Indonesia dari 135.322 kasus di tahun 2014 menjadi 322.820 kasus di tahun 2017. Salah satu provinsi Indonesia dengan prevalensi diabetes melitus yang tinggi urutan keenam yaitu provinsi Sumatera Selatan.Data di wilayah Sumatera Selatan menunjukkan bahwa sebanyak 71.237 penderita diabetes melitus (Kemenkes, 2016).

Berdasarkan data dari Rekam Medik Rumah Sakit Muhammadiyah Palembang (2018). Pasien yang menderita diabetes tipe 2 yang menjalani pemeriksaan di poliklinik penyakit dalam mengalami penurunan tiap tahunnya yaitu pada tahun 2017 sebanyak 952 pasien, dan tercatat tahun 2018 pada bulan januari 803 pasien. Sensitivitas kaki merupakan salah satu mendeteksi dapat diakibatkan oleh diabetes melitus yang di 
pengaruhi berbagai faktor seperti kadar glukosa darah yang tinggi dan tidak terkontrol, perubahan mekanisme dalam kelainan formasi tulang kaki, tekanan pada area kaki, neuropati perifer, dan penyakit arteri perifer aterosklerotik, yang semuanya terjadi dengan frekuensi dan intensitas yang tinggi pada penderita diabetes. Gangguan neuropati dan vasular merupakan faktor utama yang berkontribusi terhadap kejadian luka, luka yang terjadi akibat pasien diabetes berkaitan dengan adanya pengaruh saraf yang terdapat pada kaki yang dikenal dengan neuropati perifer, selain itu pada pasien diabetes juga mengalami gangguan sirkulasi yang berhubungan dengan Peripheral vaskular diseases. Efek dari sirkulasi ini lah yang mengakibatkan kerusakan pada saraf kaki sehingga menimbulkan gangguan pada sensitivitas kaki. (Safira, 2018). Sensitivitas kaki pada seseorang dipengaruhi oleh keadaan sendiri orang tersebut, dimana sensitivitas kaki akan mengalami peningkatan menjadi baik apabila mereka melakukan aktivitas fisik senam khususnya senam kaki akan membantu meningkatkan aliran darah didaerah kaki sehingga akan membantu menstimuli syaraf-syaraf kaki dalam menerima rangsangan. Hal ini akan meningkatkan sensitivitas kaki terutama pada penderita diabetes (Tri, 2016).

Berdasarkan beberapa data dan urgensi deteksi dini, skrining, dan DFU peneliti tertarik untuk mengetahui sensitivitas kaki pada pasien diabetes melitus tipe 2 di Rumah Sakit Muhammadiyah Palembang. Berdasarkan uraian latar belakang, maka rumusan masalah pada penelitian ini adalah bagaimana "Sensitivitas kaki Pada Penderita Diabetes Melitus tipe $2 \mathrm{Di}$ Rumah Sakit Muhammadiyah Palembang

\section{METODOLOGI PENELITIAN}

Desain Penelitian ini menggunakan metode deskriptif yaitu survei yang dilakukan terhadap sekumpulan objek yang biasanya bertujuan untuk melihat gambaran fenomena tingkat sensitivitas kaki pasien di Rumah Sakit Muhammadiyah Palembang yang terjadi didalam suatu populasi tertentu. Uji analisa dalam penelitian ini menggunakan deskriftif kuantitatif. Intervensi yang di lakukan yaitu pengukuran sensitivitas kaki dengan pengukuran 10 titik yaitu Jari kaki pertama (jempol kaki), Jari kaki ketiga (jari tengah), Jari kaki kelima (jari kelingking), Metatarsal head ke - , Metatarsal head ke - 2, Metatarsal head ke - 3, Tumit, Midfoot bagian medial, Midfoot bagian lateral, dan Bagian dorsal kaki menggunakan monofilament test. Penelitian ini di lakukan di Ruang Rawat jalan Rumah Sakit Muhammadiyah Palembang. Pada penelitian ini jumlah sampel yang akan diteliti adalah 56 respond-en. Besar sampel dalam penelitian ini adalah 56 responden yang diambil melalui teknik non random sampling dengan Kriteria inklusi

a. Pasien yang bersedia menjadi responden

b. Responden kooperatif, komunikatif

c. Pasien yang tidak memiliki kadar gula darah puasa $\geq 500 \mathrm{mg} / \mathrm{dL}$

d. Pasien yang tidak memiliki luka diabetes seperti ulkus, ganggren dan luka bakar

Penelitian ini dilakukan di Ruang Rawat Jalan Rumah Sakit Muhammadiyah Palembang yang dilaksanakan pada tanggal 8 -13 April tahun 2019. penelitian ini menggunakan instrument berupa pengukuran menggunakan monofilament testseperti beberapa penelitian yang telah digunakan. Pengukuran ini dilakukan dengan menggunakan benang monofilamen $10 \mathrm{gr}$ yang akan ditekan pada permukaan pada kulit di 10 titik rangsangan sensitivitas di kaki pada pasien diabetes melitus selama 2 detik. Pasien tidak akan mengetahui bagian mana saja akan dilakukan penekanan 
benang monofilamen $10 \mathrm{gr}$, lalu pasien akan ditanya dari 10 tekanan benang yang telah dilakukan mana saja bagian yang pasien rasakan (ardiyanti, 2014) mengatakan bahwa nilai sensitivitas tersebut dikategorikan sebagai berikut:

Skor1 : jika klien merasakan sentuhan benang monofilament pada satu titik.

Skor 0 : jika klien tidak merasakan sentuhan benang monofilament pada satu titik

Total skor akan bervariasi antara $0-10$

Analisa Univariat (Deskriptif) digunakan untuk menjelaskan atau mendeskriptipkan karakteristik umur yang dihitung oleh mean dan jenis kelamin, pendidikan, pekerjaan, dan tingkat sensitivitas mendeskriptifkan distribusi frekuensi masing - masing variabel yang diteliti.

\section{HASIL PENELITIAN}

\section{Karakteristik Responden}

Berdasarkan hasil penelitian yang dilakukan pada 60 orang pasien diabetes melitus tipe 2 di Rumah Sakit Muhammadiyah Palembang dari tanggal April 2019 sampai April 2019. Data karakteristik pasien adalah sebagai berikut.

Tabel 1

Distribusi Frekuensi Penderita Diabetes Melitus tipe 2 di Rumah Sakit Muhammadiyah Palembang

\begin{tabular}{|c|c|c|c|}
\hline No & Karakteristik & Frekuensi & Persentase (\%) \\
\hline \multirow[t]{3}{*}{1} & Jenis Kelamin & & \\
\hline & Laki-laki & 39 & $65,00 \%$ \\
\hline & Perempuan & 21 & $35,00 \%$ \\
\hline \multirow[t]{3}{*}{2} & Aktivitas Bekerja & & \\
\hline & $\mathrm{Ya}$ & 11 & $18 ., 33 \%$ \\
\hline & Tidak & 49 & $81,67 \%$ \\
\hline
\end{tabular}

$3 \quad$ Pendidikan

TS $\quad 4 \quad 6,7 \%$

SD $\quad 20 \quad 33,3 \%$

SMP $\quad 5 \quad 8,4 \%$

SMA $\quad 20 \quad 33,3 \%$

PT $11 \quad 18,3 \%$

\begin{tabular}{cccc}
\hline 4 & Olahraga & & \\
Ya & 27 & $45,00 \%$ \\
& Tidak & 33 & $55,00 \%$ \\
\hline Total & 60 & $100,00 \%$ \\
\hline
\end{tabular}

Berdasarkan Tabel diatas diketahui bahwa dari 39 orang (65,00\%) dari 60 penderita Diabets Melitus tipe 2 berjenis kelamin laki-laki, dan 21 orang $(35,00 \%)$ berjenis kelamin perempuan. Dengan demikian, jenis kelamin penderita Diabetes Melitus tipe 2 dominan adalah laki-laki. Terdapat 11 orang (18,33\%) dari
60 pasien penderita Diabetes Melitus tipe 2 melakukan aktivitas bekerja, dan 49 orang $(81,67 \%)$ tidak bekerja. Dengan demikian, pasien penderita Diabets Melitus tipe 2 dominan tidak memiliki aktivitas bekerja. Terdapat 31 orang $(51,67 \%)$ dari 60 pasien penderita Diabets Melitus tipe 2 dengan riwayat pendidikan tidak sekolah 4 orang (18,33\%), SD 20 orang (33,3\%), SMP 5 orang $(8,3 \%)$, SMA 20 orang $(33,3 \%)$, 
dan 11 orang (18,3\%). Terdapat 27 orang $(45,00 \%)$ dari 60 pasien penderita Diabetes Melitus tipe 2 melakukan olahraga, dan 33 orang $(55,00 \%)$ tidak berolahraga. Dengan demikian, pasien penderita Diabets Melitus tipe 2 dominan tidak melakukan aktivitas olahraga.

Tabel 2

Karakteristik Penderita Diabetes Melitus tipe 2 di Rumah Sakit Muhammadiyah Palembang $(n=60)$

\begin{tabular}{|c|c|c|c|c|c|c|c|}
\hline \multirow{2}{*}{ Karakteristik } & \multirow{2}{*}{ Min } & \multirow{2}{*}{ Max } & \multirow{2}{*}{ Mean } & \multirow{2}{*}{ Median } & \multirow{2}{*}{ Sd } & \multicolumn{2}{|c|}{ Cl 95\% } \\
\hline & & & & & & Lower & Upper \\
\hline Umur & 50 & 70 & 59,45 & 59,00 & 6,236 & 57,77 & 61,14 \\
\hline $\begin{array}{l}\text { Lamanya } \\
\text { menderita } \\
\text { diabetes }\end{array}$ & 1 & 7 & 3,58 & 3,00 & 1,892 & 3,07 & 4,09 \\
\hline
\end{tabular}

Dari table diatas didapatkan hasil uji analisis diantaranya pada Usia Responden rata rata adalah 59,45 tahun dengan standar deviasi 16,236, hasil uji anlisis kedua yaitu Lamanya Waktu menderita diabetes dengan rata rata 3,58 tahun dengan standar deviasi 1,892.

2. Gambaran Tingkat Sensivitas Kaki Penderita Diabetes Melitus Tipe 2

Tingkat sensivitas kaki penderita Diabetes Mellitus tipe 2 dari 60 responden yang diukur menggunakan penusukan benang Monofilamen pada jari kaki pertama (jempol kaki), jari kaki ketiga (jari tengah), jari kaki kelima (jari kelingking), Metatarsal head ke - 1, Metatarsal head ke - 2, Metatarsal head ke - 3, tumit, Midfoot bagian medial, Midfoot bagian lateral, dan bagian dorsal kaki. Hasil penusukan benang tersebut dapat dilihat pada tabel berikut.

Tabel 3

Distribusi Frekuensi Tingkat Sensivitas Kaki Penderita Diabetes Melitus Tipe 2

\begin{tabular}{|c|c|c|c|}
\hline No & Tingkat Sensivitas & Frekuensi & Persentase (\%) \\
\hline \multirow[t]{3}{*}{1} & Jempol Kaki & & \\
\hline & Tidak ada rasa & 12 & $20,00 \%$ \\
\hline & Ada rasa & 48 & $80,00 \%$ \\
\hline \multirow[t]{3}{*}{2} & Jari Tengah & & \\
\hline & Tidak ada rasa & 21 & $35,00 \%$ \\
\hline & Ada rasa & 39 & $65,00 \%$ \\
\hline \multirow[t]{3}{*}{3} & Jari Kelingking & & \\
\hline & Tidak ada rasa & 18 & 30,00 \\
\hline & Ada rasa & 42 & 70,00 \\
\hline \multirow[t]{3}{*}{4} & Metatarsal head ke - 1 & & \\
\hline & Tidak ada rasa & 23 & $38,33 \%$ \\
\hline & Ada rasa & 37 & $61,67 \%$ \\
\hline
\end{tabular}




\begin{tabular}{|c|c|c|c|}
\hline \multirow[t]{3}{*}{5} & \multicolumn{3}{|l|}{ Metatarsal head ke - 2} \\
\hline & Tidak ada rasa & 17 & $28,33 \%$ \\
\hline & Ada rasa & 43 & $71,67 \%$ \\
\hline \multirow[t]{3}{*}{6} & Metatarsal head ke - 3 & & \\
\hline & Tidak ada rasa & 20 & $33,33 \%$ \\
\hline & Ada rasa & 40 & $66,67 \%$ \\
\hline \multirow[t]{3}{*}{7} & Tumit & & \\
\hline & Tidak ada rasa & 18 & $30,00 \%$ \\
\hline & Ada rasa & 42 & $70,00 \%$ \\
\hline \multirow[t]{3}{*}{8} & Midfoot bagian medial & & \\
\hline & Tidak ada rasa & 22 & 36,67 \\
\hline & Ada rasa & 38 & 63,33 \\
\hline \multirow[t]{3}{*}{9} & Midfoot bagian lateral & & \\
\hline & Tidak ada rasa & 20 & $33,33 \%$ \\
\hline & Ada rasa & 40 & $66,67 \%$ \\
\hline \multirow[t]{4}{*}{10} & Dorsal kaki & & \\
\hline & Tidak ada rasa & 25 & $41,67 \%$ \\
\hline & Ada rasa & 35 & $58,33 \%$ \\
\hline & Total & 60 & $100,00 \%$ \\
\hline
\end{tabular}

Tabel di atas, menyatakan bahwa 12 orang $(20,00 \%)$ dari 60 pasien penderita Diabets Melitus tipe 2 tidak ada rasa dari penusukan benang Monofilamen pada jempol kaki, sedangkan 48 orang $(80,00 \%)$ menyatakan ada. Dengan demikian, dominan pasien menyatakan ada rasa dari penusukan benang Monofilamen pada jempol kaki.

Terdapat 21 orang (35,00\%) dari 60 pasien penderita Diabets Melitus tipe 2 tidak ada rasa dari penusukan benang Monofilamen pada jari tengah, sedangkan 39 orang $(65,00 \%)$ menyatakan ada. Dengan demikian, dominan pasien menyatakan ada rasa dari penusukan benang Monofilamen pada jari tengah.

Terdapat 18 orang $(30,00 \%)$ dari 60 pasien penderita Diabets Melitus tipe 2 tidak ada rasa dari penusukan benang Monofilamen pada jari kelingking, sedangkan 42 orang $(70,00 \%)$ menyatakan ada. Dengan demikian, dominan pasien menyatakan ada rasa dari penusukan benang Monofilamen pada jari kelingking.

Terdapat 23 orang $(38,33 \%)$ dari 60 pasien penderita Diabets Melitus tipe 2 tidak ada rasa dari penusukan benang Monofilamen pada metatorsal head ke-1, sedangkan 37 orang $(61,67 \%)$ menyatakan ada. Dengan demikian, dominan pasien menyatakan ada rasa dari penusukan benang Monofilamen pada metatorsal head ke-1.

Terdapat 17 orang $(28,33 \%)$ dari 60 pasien penderita Diabets Melitus tipe 2 tidak ada rasa dari penusukan benang Monofilamen pada metatorsal head ke-2, sedangkan 43 orang $(71,67 \%)$ menyatakan ada. Dengan demikian, dominan pasien menyatakan ada rasa dari penusukan benang Monofilamen pada metatorsal head ke-2.

Terdapat 20 orang $(33,33 \%)$ dari 60 pasien penderita Diabets Melitus tipe 2 tidak ada rasa dari penusukan benang Monofilamen pada metatorsal head ke-3, sedangkan 40 orang $(66,67 \%)$ menyatakan ada. Dengan demikian, dominan pasien menyatakan ada rasa dari penusukan benang Monofilamen pada metatorsal head ke-3

Terdapat 18 orang $(30,00 \%)$ dari 60 pasien penderita Diabets Melitus tipe 2 
tidak ada rasa dari penusukan benang Monofilamen pada tumit, sedangkan 42 orang $(70,00 \%)$ menyatakan ada. Dengan demikian, dominan pasien menyatakan ada rasa dari penusukan benang Monofilamen pada tumit.

Terdapat 22 orang $(36,67 \%)$ dari 60 pasien penderita Diabets Melitus tipe 2 tidak ada rasa dari penusukan benang Monofilamen pada midfoot bagian medial, sedangkan 38 orang $(63,33 \%)$ menyatakan ada. Dengan demikian, dominan pasien menyatakan ada rasa dari penusukan benang Monofilamen pada midfoot bagian medial.

Terdapat 20 orang (33,33\%) dari 60 pasien penderita Diabets Melitus tipe 2 tidak ada rasa dari penusukan benang Monofilamen pada midfoot bagian lateral, sedangkan 40 orang $(66,67 \%)$ menyatakan ada. Dengan demikian, dominan pasien menyatakan ada rasa dari penusukan benang Monofilamen pada midfoot bagian lateral.

Terdapat 25 orang $(41,67 \%)$ dari 60 pasien penderita Diabets Melitus tipe 2 tidak ada rasa dari penusukan benang Monofilamen pada dorsal kaki, sedangkan 35 orang $(58,33 \%)$ menyatakan ada. Dengan demikian, dominan pasien menyatakan ada rasa dari penusukan benang Monofilamen pada dorsalkaki.

3. Gambaran Skor Rata-rata Tingkat Sensivitas Kaki Penderita Diabetes Melitus Tipe 2

Rata-rata tingkat pengukuran sensivitas penderita Diabetes Mellitus tipe 2 di Rumah Sakit Muhammadiyah Palembang dapat dilihat pada tabel berikut

Table 4

Gambaran Skor Rata-rata Tingkat Sensivitas Kaki Penderita

Diabetes Melitus Tipe 2

\begin{tabular}{llllllr}
\hline \multicolumn{1}{c}{ Variabel } & Mean & Median & SD & Min & Maks & 95\% Cl \\
\hline $\begin{array}{l}\text { Tingkat sensitivitas } \\
\text { kaki penderita diabetes } \\
\text { melitus tipe2 }\end{array}$ & 6,73 & 7,00 & 1,43 & 4 & 10 & $6,37-7,10$ \\
\hline
\end{tabular}

Tabel diatas menyatakan bahwa dari 60responden, skor mean (rata-rata) dari tingkat sensitivitas kaki tipe 2 adalah 6,73 skor median (nilai tengah) 7,00 dan standar deviasi 1,4 skor sensitivitas kaki tertinggi 10 dan skor terendah 4. Dari estimasi interval dapat di simpulkan $95 \%$ di yakini bahwa sensitivitas kaki penderita diabetes melitus tipe 2 di antara nya 6,73 sampai dengan 7,10

\section{PEMBAHASAN}

Dua patofisiologi utama yang mendasari terjadinya kasus Diabates Melitus tipe 2 secara genetik menurut Decroli (2019) adalah resistensi insulin dan defek fungsi sel beta pankreas. Resistensi insulin merupakan kondisi umum bagi orang-orang dengan berat badan overweight atau obesitas. Insulin tidak dapat bekerja secara optimal di sel otot, lemak, dan hati sehingga memaksa pankreas mengkompensasi untuk memproduksi insulin lebih banyak. 
Ketika produksi insulin oleh sel beta mengkompensasi peningkatan resistensi insulin, maka kadar glukosa darah akan meningkat, pada saatnya akan terjadi hiperglikemia kronik. Hiperglikemia kronik pada Diabates Melitus tipe 2 semakin merusak sel beta di satu sisi dan memperburuk resistensi insulin di sisi lain, sehingga penyakit Diabates Melitus tipe 2 semakin progresif.

Penelitian Trisnawati (2012), menyebutkan dari 50 sampel pasien DM Tipe II di Puskesmas Kecamatan Cengkareng Jakarta Barat 62,1\% adalah perempuan. Hasil penelitian dengan jumlah yang berbeda dilakukan oleh Yuliani (2014) dari 156 sampel, 57\% adalah pasien perempuan DM dengan risiko mengalami penyakit jantung korener di di RSUP. Dr. M. Djamil Padang dan RS Khusus Jantung Sumatera Barat.

Berdasarkan hasil penelitian diperoleh gambaran mengenai tingkat sensitivitas kaki pada penderita Diabetes Melitus tipe 2 di Rumah Sakit Muhammadiyah Palembang dengan menggunakan penusukan benang Monofilamen pada jari kaki pertama (jempol kaki), jari kaki ketiga (jari tengah), jari kaki kelima (jari kelingking), Metatarsal head ke - 1, Metatarsal head ke - 2, Metatarsal head ke - 3, tumit, Midfoot bagian medial, Midfoot bagian lateral, dan bagian dorsal kaki.

Hasil penelitian menyatakan bahwa penusukan benang Monofilamen pada kaki penderita Diabetes Melitus tipe 2 diperoleh 12 orang $(20,00 \%)$ dari 60 pasien penderita Diabets Melitus tipe 2 tidak ada rasa dari penusukan benang Monofilamen pada jempol kaki, sedangkan 48 orang $(80,00 \%)$ menyatakan ada rasa. Tidak adanya rasa pada jempul kaki setelah dilakukan penusukan benang Monofilamen

pankreas tidak adekuat guna disebabkan oleh banyak kondisi yang berbeda-beda dan sering kali disertai rasa seperti ditusuk banyak jarum. Kondisi demikian menunjukkan bahwa penyakit telah menyerang sistem saraf pusat pada pasien.

Lebih lanjut Suyono (2016) menyatakan pasien DM tipe 2 merupakan jenis DM yang paling banyak ditemukan (lebih dari 90\%) dan akan timbul makin sering setelah umur 40 tahun, dengan catatan pada dekade ke-7 kekerapan DM mencapai 3 sampai 4 kali lebih tinggi daripada rata-rata orang dewasa. Studi Yulianto (2015), menyebutkan karakteristik umur pasien Diabetes Melitus tipe 2 komplikasi hipertensi dan tanpa komplikasi hipertensi di RSUD Dr. Moewardi Surakarta $80 \%$ berumur di atas 40 tahun. Menurut Pangemanan (2014), seseorang yang berumur di atas 46 tahun memiliki peningkatan resiko terhadap terjadinya DM dan intoleransi glukosa yang disebabkan oleh faktor degeneratif yaitu menurunya fungsi tubuh, khususnya kemampuan dari sel $\beta$ dalam memproduksi insulin untuk memetabolisme glukosa. Sementara pendapat Tandra (2017), kemungkinan lain terjadinya diabetes ini adalah karena sel-sel jaringan tubuh tidak peka atau resisten terhadap insulin karena faktor usia.

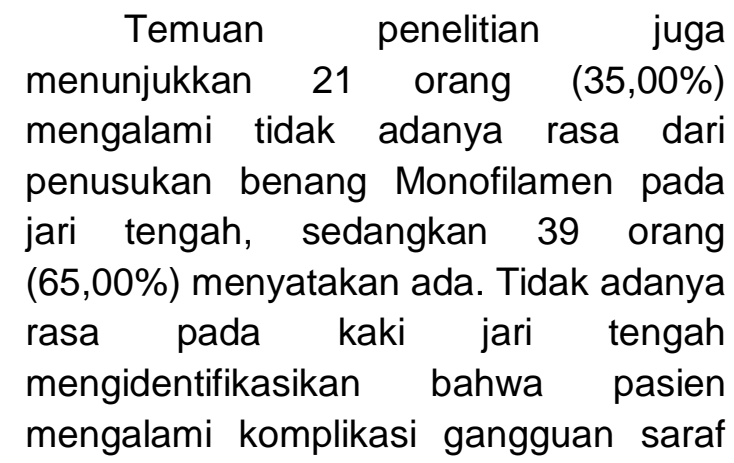


dari penyakit Diabetes Melitus yang dialaminya.

Terdapat 18 orang $(30,00 \%)$ dari 60 pasien penderita Diabets Melitus tipe 2 tidak ada rasa dari penusukan benang Monofilamen pada jari kelingking, sedangkan 42 orang (70,00\%) menyatakan ada. Temuan ini mengidentifikasikan bahwa pasien mengalami gangguan saraf median yang tertekan atau terhimpit.

Ditemukan 23 orang $(38,33 \%)$ dari 60 pasien penderita Diabets Melitus tipe 2 tidak ada rasa dari penusukan benang Monofilamen pada metatorsal head ke-1, sedangkan 37 orang $(61,67 \%)$ menyatakan ada. Temuan ini menunjukkan bahwa pasien mengalami aliran darah yang buruk. Hal ini terjadi karena kerusakan pembuluh darah yangdisebabkan oleh kadar gula darah yang tinggi dalam waktu lama. Aliran darah yang terganggu menyebabkan kaki tidak mendapatkan nutrisi yang cukup, sehingga kulit kaki menjadi lemah, mudah luka dan sukar sembuh jika terjadi luka.

Donald et al (2013), menyatakan komplikasi DM akan mengakibatkan komplikasi fisik seperti hipertensi, gangren, katarak, obesitas, kehilangan berat badan dan gangguan seksual yang akan menurunkan kualitas hidup. Selain menyerang dari segi fisik, namun juga mengakibatkan kerusakan pada mental. $\mathrm{Hal}$ ini terjadi disebabkan penderita terkadang memiliki depresi, rasa gelisah dan skizofrenia yang menyebabkan turunnya kualitas hidup. Selama penelitian berlangsung dengan responden di desa Pademawu, terdapat 1-3 responden yang telah mengalami komplikasi yang sangat parah, terdapat gangren di kulit kaki yang bahkan membusuk sehingga menyebabkan responden/pasien DM tersebut tidak dapat berjalan. Ada juga pasien yang telah mengalami amputasi pada kaki akibat gangren kulit yang parah sehingga terpaksa kehilangan jari-jari kakinya. Pasien yang mengalami komplikasi yang parah ini selalu mengeluh mengenai dirinya yang tak mampu melakukan aktivitas seperti biasa bahkan terkadang terdapat pasien yang merasa tidak berguna dan selalu berkecil hati. Perasaan cemas yang berlebihan akan mengakibatkan imunitas pasien semakin menurun dan berakibat langsung terhadap kualitas hidup.

Terdapat 17 orang $(28,33 \%)$ dari 60 pasien penderita Diabets Melitus tipe 2 tidak ada rasa dari penusukan benang Monofilamen pada metatorsal head ke-2, sedangkan 43 orang $(71,67 \%)$ menyatakan ada. Tidak adanya rasa pada pasien dikarenakan mengalami kerusakan saraf. Hal ini terjadi karena kadargula darah yang tinggi dalam waktu lama. Kerusakan saraf menyebabkan kepekaan seorang pasien DM terhadap rasa nyeri menjadi berkurang.

Salah satu resiko yang terjadi pada pasien DM adalah keterlambatan diagnosis kadar $\mathrm{HbA1c}$. Kadar HbA1c pada pasien DM berhubungan dengan meningkatnya resiko komplikasi. Temuan utama studi diabetes, Diabetes control and complication trial (DCCT) telah menunjukkan pentingnya tes HbA1C. Studi menunjukkan bahwa menurunkan angka $\mathrm{HbA} 1 \mathrm{C}$ dapat menunda atau mencegah komplikasi kronis. Studi juga menunjukkan bahwa menurunkan kadar hemoglobin $\mathrm{HbA} 1 \mathrm{C}$ agar tetap dalam kadar normal dapat meningkatkan peluang seseorang untuk tetap sehat. Pengendalian DM tipe 1 dengan $\mathrm{HbA1C}$ yang baik dapat mengurangi komplikasi kronik DM antara 20-30\%. Bahkan hasil dari TheUnited 
Kingdom Prospective Diabetes Study (UKPDS) menunjukkan setiap penurunan $1 \%$ dari $\mathrm{HbA} 1 \mathrm{C}$ (misal dari 9 ke $8 \%$ ), akan menurunkan risiko komplikasi sebesar 35\% (dalam Delamater, 2006). Keterlambatan diagnosa $\mathrm{HbA1C}$ pada pasien DM beresiko terhadap timbulnya komplikasi. Papatungan dan Sanusi (2014) melaporkan bahwa rata-rata keterlambatan pemeriksaan $\mathrm{HbA} 1 \mathrm{C}$ sejak onset hingga diagnosis ditegakkan rata-rata adalah 7 tahun.

Penelitian juga menyatakan bahwa terdapat 20 orang $(33,33 \%)$ tidak ada rasa dari penusukan benang Monofilamen pada metatorsal head ke-3, sedangkan 40 orang $(66,67 \%)$ menyatakan ada. Terdapat 18 orang $(30,00 \%)$ dari 60 pasien penderita Diabets Melitus tipe 2 tidak ada rasa dari penusukan benang Monofilamen pada tumit, sedangkan 42 orang $(70,00 \%)$ menyatakan ada. Dengan demikian, dominan pasien menyatakan ada rasa dari penusukan benang Monofilamen pada tumit.

Hasil penusukan benang

Monofilamen pada midfoot bagian medial terhadap pasien diperoleh 22 orang $(36,67 \%)$ tidak ada rasa, dan 38 orang $(63,33 \%)$ menyatakan ada. Lain halnya hasil penusukan pada midfoot bagian lateral diperoleh 20 orang $(33,33 \%)$ tidak ada rasa, dan 40 orang $(66,67 \%)$ menyatakan ada. Sedangkan hasil penusukan pada dorsal kaki, dinyatakan 25 orang $(41,67 \%)$ dari 60 pasien penderita Diabets Melitus tipe 2 tidak ada rasa, dan selebihnya yaitu 35 orang $(58,33 \%)$ menyatakan ada.

Penderita DM tipe 2 tentunya memiliki masa-masa sulit seperti berbenah diri, sering mengontrol gula darah, pola makan, dan aktivitas. Tentu saja segala hal ini membutuhkan bantuan atau dukungan dari orang sekitar terutama keluarga. Penderita diabetes yang sering menceritakan segala kondisi dengan orang terdekat, maka diharapkan membantu dalam kontrol diet, kecemasan, pengobatan serta dapat meningkatkan kualitas hidup penderita diabetes. Herdianti (2017), juga menyatakan penderita DM tipe 2 yang mendapat ukungan keluarga yang kurang memiliki risiko 5,14 kali kualitas hidup yang buruk daripada penderita DM tipe yang memiliki dukungan keluarga yang baik. Dukungan keluarga diyakini sangat membantu pasien DM tipe 2 dalam melakukan tindakan perawatan seperti pengecekan cek gula darah secara teratur dan minum obat. Penelitian sama yang lain adalah Retnowati (2015), yang menghasilkan $p$ value $=0,000$ sehingga dukungan keluarga memiliki hubungan dengan kualitas hidup penderita DM tipe 2 . Semakin tinggi dukungan yang diperoleh maka semakin rendah derajat depresi yang dialami penderita DM sehingga kualitas hidupnya akan semakin tinggi, begitu pula sebaliknya. Dukungan keluarga mempunyai dampak terhadap kesehatan fisik dan mental anggota keluarga yang menderita DM.

\section{KESIMPULAN}

1. Rata-rata responden berusia 59,45 tahun dan sebgaian besar berjenis kelamin laki-laki (65\%), dan tidak bekerja $(81,67 \%)$ dengan riwayat pendidikan tinggi serta tidak pernah melakukan olahraga (55\%) dengan lama menderita DM rata-rata 3,58 tahun.

2. Terdapat nilai sensitivitas kaki yang tidak ada rasa dengan frekuensi tertinggi yaitu pada dorsal kaki sebanyak 25 orang $(41,67 \%)$, metatarsal head ke-1 sebanyak 23 
orang (38,33\%), Midfoot bagian Medial sebanyak 22 orang $(36,67)$, jari tengah sebnayk 21 orang (35\%), metatarsal head ke-3 sebanyak 20 orang (33,33\%), Midfoot bagian lateral sebanyak 20 orang (33,33\%), Tumit sebanyak 18 orang (30\%), jari kelingking sebanyak 18 orang (30\%), metatarsal haed ke-2 sebanyak 17 orang $(28,33 \%)$, dan terendah yaitu pada jempol kaki dengan frekuensi 12 responden (20\%).

\section{SARAN}

1. Bagi Rumah Sakit

Untuk rumah sakit muhammadiyah palembang khususnya ruang rawat jalan, diharapakn dapat melakukan peningkatan edukasi ke pasien untuk mencegah terjadinya komplikasi seperti DFU dan meningkatkan promosi kesehatan akan pentingnya merubah perilaku hidup sehat.

2. Bagi STIKes Muhammadiyah Palembang

Diharapkan institusi pendidikan dapat berperan aktif terhadap edukasi pencegahan Diabetic Foot Ulcer serta kesadaran dan komplikasi tersebut.

3. Bagi Peneliti Selanjutnya

Bagi peneliti selanjutnya di harapkan mahasiswa yang nantinya akan melakukan penelitian mengenai sensitivitas kaki pada penderita diabetes melitus tipe 2, dapat meneruskan dan menyempurnakan penelitian ini untuk mengetahui apakah ada hubungannya diabetic foot ulcer dengan karakteristik responden seperti jenis kelamin, usia dan lama menderita DM.

\section{DAFTAR PUSTAKA}

American Diabetes Association (ADA). (2017). Diagnosis And Classification Of Diabetes Melitus. American Diabetes Care, Vol.38, pp: 8-16.

Aldnyana, L., Hensen, Budhiarta, A.G., (2012). Penatalaksaan Pasien Diabetes Melitus di poliklinik Rumah Sakit Sanglah Denpasar. Jurnal Penyakit Dalam. Vol 7: pp 186-192.

Arifin, Augusta L., 2013, Panduan Terapi Diabetes Melitus Tipe 2 Terkini, Http://respository.unpad.ac.id (di akses pada 23november 2013).

Billous, R \& Donelly, R. (2014). Buku panduan diabetes edisi IV. Jakarta : bumi medika

Budiman, (2011). Penelitian kesehatan buku pertama. Jakarta : Redika aditama

Centers for Disease Control and Prevention (CDC). (2012). Diabetes report card2012. Diunduh pada tanggal 20 Februari 2014 darihttp://www.cdc.gov/diabetes/p ubs/pdf/DiabetesReportCard.pdf

Damayanti, Santi., (2015). Penatalaksanaan diabetes melitus. Yogyakarta: Nuha Medika.

Fatimah, R. N.(2015).Diabetes Mellitus Tipe 2.J Majority, 4(5), 93-101.

Febrianti, Winda. (2018). Gambaran ankle brachial index dan skore pengkanjian luka pada pasien ulkus kaki diabetic di RSUD Dr Slamet Garud diunduh dari : 3 maret 2019

Hidayati, Nur. 2015. Pemberian senam kaki diabetes dengan bola plastic terhadap tingkat sensitivitas kaki pada asuhan keperawatan diabetes di unduh dari : 1 
maret 2019

http://digilib.stikeskusumahusada. ac.id.

International diabetes federation. (2010). Million unite for diabetes awareness on world diabetes day 2010.(online). (http://www.idf.org/n ode/4369/ diakses pada tanggal 7 april 2017.

Karinda, R. A. (2013). Pengaruh Senam Sehat Diabetes Melitus Terhadap Profil Li[Id Klien Diabetes Melitus Tipe 2 Di Wilayah Kerja Pusksmas Patrang Kabupaten Jember. Skripsi Program Studi IImu Keperawatan Universitas Jember.

Khardori, R.(2013). Medscape endocrine diabetes melitus type 2. di unduh januari januari $21 \quad 2017$ dari medscape.

Natalia, et al. 2013. Efektivitas senam kaki diabetic dengan tempurung kelapa terhadap tinggkat sensitivitas kaki pada pasien diabetes melitus pada pasien diabetes melitus tipe 2 diunduh Dari :3 maret 2019https://repository.unri.ac.id

Noor, Restyana. 2015. Diabetes melitus tipe 2 diunduh Dari : 2 maret 2019

http://juke.kedokteran.unila.ac.id

Notoadmojo, (2013). Metodologi penelitian kesehatan. Jakartra :Rineka cipta

Nursalam, (2013). Metodologi ilmu keperawatan (ED 3). Jakarta : Salemba Medika

Oktaviah, D. (2014). Efektivitas Senam Kaki Diabetik Dengan Bola Plastik Terhadap Tingkat Sensitivitas Kaki Pada Pasien Diabetes Melitus Tipe 2. ( Skrpsi). Universitas Riau.
PERKENI. (2012). In C. E Tanto, Kapita Selekta Kedokteran Esenstial Of Medicine. Jakarta: Media Aesculapius

Prasetyani, D. et al (2017). Karakteristik pasien diabetes melitus tipe II di puskesmas cilacap tengah 1 dan 2. (Universitas

Rendy, ClevoM. Dan Margareth (2012). Asuhan Keperawatan Medical Penyakit Dalam. Yogjakarta: Nuha Medika.

Rusandi, D. (2015). Pengaruh Senam Kaki Diabetes Melitus Terhadap Tingkat Sensitivitas Kaki dan Kadar Glukosa Darah pada Penderita Diabetes Melitus Di Kelurahan BanyuRaden Gamping Sleman (Skripsi). Universitas

Rohana, R (2014). Melakukan Senam Kaki diabetes Melitus Dengan Koran Terhadap Sensitivitas Kaki Pada Diabetes Melitus Tipe $2 \mathrm{Di}$ Ruang Mawar RSUD

Riskesdas. (2018). Riset Kesehatan Dasar, Kementrian Kesehatan RI. (http://depkes.go.id).

Safira K, 2018. Buku pintar diabetes. Yogyakarta: Nuha Medika

Setiyohadi, et. Al. (2012) Editors. Buku IImu Penyakit Dalam Jilid 3. Jakarta: Departemen IImu Penyakit Dalam Fakultas Kedokteran Univeritas Indonesia.

Soegondo, Sidartawan, Pradana Soewondo, Imam Subekti, ed. penatalaksanaan diabetes miletus terpadu, Jakarta: balai penerbit FKUI: 2013.

Suyono, S.,(2016). Penatalaksanaan diabetes melitus terpadu: Patofisologi Diabetes Militus, Fakultas Kedokteran Indonesia, Jakarta.

Perkeni. (2012). Konsesus pengelolahan dan pencegahan diabetes melitus 
tipe 2 di indonesia.

http:/www.pbpapdi.org. di akses tanggal 1 oktober 2015.

Purnamasari D. (2012). Diagnosis Dan Klasifikasi Diabetes Melitus. Buku Ajar IImu Penyakit Dalam, Jilid III. Ed ke-5. Jakarta: Interna Publishing.

Priyanto, S. (2012). Pengaruh Senam Kaki Terhadapa Sensitivitas Kaki \& Kadar Gula Darah Aggregat Lansia Diabetes Melitus Di Magelang. Thesis IImu Keperawatan. Universitas Indonesia.

Tandra, hans.,(2018) . Panduan lengkap mengenal dan mengatasi diabetes dengan cepat dan mudah. Jakarta: Gramedia pustaka.

Tjokprawiro, Askandar. (2015). Hidup Sehat Dan Bahagia Bersama Diabetes Melitus. Jakarta: Gramedia Pustaka Utama.

World Health Organisation (WHO). 2016. World Health Statistics. Dunia: $\mathrm{WHO}$

Yahya, N. (2018). Hidup sehat dengan diabetes.Jakarta: Selemba Medika.

Zardi, Elia Daini,(2012). Karakteristik Penyakit Diabetes Melitus (DM) tipe 2 yang di rawat di Rumah Sakit Dr. M. Jamil Padang tahun 2012 